\title{
Układy sterowania hamulcami opracowane przez IPS „TABOR” dla modernizowanych lokomotyw manewrowych
}

\author{
$W$ artykule zaprezentowano uktady sterowania hamulcami opracowane \\ przez IPS „,TABOR”, które znalazły zastosowanie w manewrowych lokomo- \\ tywach spalinowych $i$ elektrycznych poddawanych modernizacji. Zamiesz- \\ czone $w$ artykule opisy budowy $i$ działania zespotów charakterystycznych dla \\ elektropneumatycznych i mikroprocesorowych uktadów sterowania ilustruja \\ rozwój tych układów w ostatnich dwudziestu latach. Efektem tego rozwoju \\ jest przedstawiona $w$ tym artykule propozycja uktadu sterowania z uniwer- \\ salna tablica pneumatycznq o budowie modutowej.
}

\section{WSTĘP}

W ostatnich dwudziestu latach modernizacji poddawano najczęściej spalinowe lokomotywy manewrowe dwóch najliczniej eksploatowanych typów, to jest wyprodukowane w Fabloku lokomotywy typu 6D (Ls 800 - wersja dla przemysłu) oraz sprowadzane z Rosji lokomotywy typu TEM2. Lokomotywy tych typów otrzymały na PKP oznaczenia serii odpowiednio SM 42 i SM 48. Podstawowym celem modernizacji tych lokomotyw było wyposażenie ich w silniki spalinowe spełniające współczesne wymagania dotyczące zużycia paliwa i czystości spalin. Po wielu latach eksploatacji konieczne stała się również wymiana zużytych aparatów układu pneumatycznego hamulca na nowe. Istotnym celem modernizacji było też wyposażenie każdej z tych lokomotyw w dwa kompletne stanowiska maszynisty zgodne $\mathrm{z}$ zasadami ergonomii i zapewniające maszyniście lepsze jak dotychczas możliwości obserwacji szlaku. Warunkiem koniecznym takiej modernizacji kabin maszynisty było wyeliminowanie dotychczasowych, elektromechanicznych nastawników jazdy oraz głównych i dodatkowych zaworów maszynisty wraz $\mathrm{z}$ niezbędnymi zbiornikami, filtrami, zaworami odcinającymi i przewodami pneumatycznymi oraz zastapienie ich ergonomicznymi elektrycznymi manipulatorami służącymi do sterowania napędem, hamulcem zespolonym pociagu i hamulcem dodatkowym lokomotywy. Aparaty pneumatyczne i elektropneumatyczne pośredniczące w sterowaniu wyżej wymienionymi hamulcami należało umieścić poza kabinami maszynisty. Rozwiązanie stosowane w nowoczesnych lokomotywach polega na zintegrowaniu wszystkich aparatów pośredniczących w sterowaniu hamulcami lokomotywy i pociagu nią prowadzonego oraz aparatów wykonujących rozrząd sprężonego powietrza na tablicy pneumatycznej; sterowanie $\mathrm{z}$ aktywnego stanowiska maszynisty hamulcami i rozrządem sprężonego powietrza odbywa się wówczas za pomocą sygnałów elektrycznych. Takie rozwiązanie zastosowano też podczas modernizacji wyżej wymienionych lokomotyw.

IPS „TABOR”uczestniczył w kilku modernizacjach spalinowych lokomotyw manewrowych wyżej wymienionych typów oraz w modernizacji elektrycznej lokomotywy manewrowej typu 405E (seria PKP EM 10) opracowując dla nich układy sterowania hamulcami i rozrządem sprężonego powietrza oraz dostarczając najważniejsze zespoły tych układów, takie jak tablice pneumatyczne, elektryczne manipulatory hamulców i kabinowe zawory hamulca bezpieczeństwa (patrz tabele 1 i 2 ). W artykule tym przedstawiono rozwój tych układów od prostych układów elektropneumatycznych, w które wyposażono lokomotywy modernizowane na przełomie wieków, do zastosowanych ostatnio układów wykorzystujących sterowniki mikroprocesorowe i sieci informatyczne. Przedstawiono w nim również najnowsze rozwiązanie układu sterowania hamulcami i rozrządem sprężonego powietrza, który może znaleźć zastosowanie w modernizowanych lub nowych lokomotywach manewrowych; podstawowym zespołem tego układu jest uniwersalna tablica pneumatyczna o budowie modułowej (wersja z jednym zaworem rozrządczym). 
Tabela 1.

Elementy produkcji IPS „TABOR”zastosowane w elektropneumatycznych ukladach sterowania hamulcami zmodernizowanych lokomotyw manewrowych

\begin{tabular}{|c|c|c|c|c|c|c|}
\hline \multirow[b]{2}{*}{$\frac{4}{2}$} & \multicolumn{3}{|c|}{ Dane lokomotywy } & \multirow[b]{2}{*}{ Nazwa urządzenia } & \multirow{2}{*}{$\begin{array}{l}\text { Typ } \\
\text { urządzenia }\end{array}$} & \multirow{2}{*}{$\begin{array}{l}50 \\
5 \\
5 \\
5\end{array}$} \\
\hline & Typ & $\begin{array}{l}\text { Moder- } \\
\text { nizator }\end{array}$ & $\begin{array}{c}\text { Użyt- } \\
\text { kownik }\end{array}$ & & & \\
\hline \multirow{4}{*}{ よ̆ } & \multirow{4}{*}{ 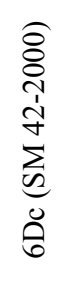 } & \multirow{4}{*}{$\begin{array}{c}\text { ZNLS } \\
\text { Piła }\end{array}$} & \multirow{4}{*}{$\begin{array}{l}\text { PKP } \\
\text { Cargo }\end{array}$} & $\begin{array}{l}\text { Kabinowa tablica pneumatyczna } \\
\text { lokomotywy manewrowej }\end{array}$ & 45ZL 10-1 & \\
\hline & & & & $\begin{array}{l}\text { Zespół hamowania nagłego } \\
\text { sterowany elektrycznie }\end{array}$ & 20ZH 05-1 & \\
\hline & & & & Manipulator HZ-U & $1 \mathrm{ZH} 05-6$ & \\
\hline & & & & Manipulator HD & $1 \mathrm{ZH} 06-4$ & \\
\hline \multirow{4}{*}{$\stackrel{\infty}{\Omega}$} & \multirow{4}{*}{$\begin{array}{l}\bar{\delta} \\
8 \\
0 \\
0 \\
n\end{array}$} & \multirow{8}{*}{\multicolumn{2}{|c|}{$\begin{array}{c}\text { PTKiGK } \\
\text { Rybnik }\end{array}$}} & $\begin{array}{l}\text { Tablica pneumatyczna lokomotywy } \\
\text { manewrowej }\end{array}$ & 45ZL 20-2 & \\
\hline & & & & Manipulator HZ-U & $1 \mathrm{ZH} 05-1$ & \\
\hline & & & & Manipulator HD & $1 \mathrm{ZH} 06-1$ & \\
\hline & & & & Zawór hamulca bezpieczeństwa G1 & 7ZH 33-1 & \\
\hline \multirow{4}{*}{$\stackrel{\overbrace{}}{\circledR}$} & \multirow{4}{*}{$\begin{array}{l}1 \\
\delta \\
\delta \\
0 \\
n \\
n\end{array}$} & & & Tablica pneumatyczna lokomotywy & 45ZL 31-1 & \\
\hline & & & & Manipulator HZ-U & $1 \mathrm{ZH} 05-3$ & \\
\hline & & & & Manipulator HD & $1 \mathrm{ZH} 06-3$ & \\
\hline & & & & Zawór hamulca bezpieczeństwa G1 & 7ZH 33-1 & \\
\hline \multirow{8}{*}{ ڤิ) } & \multirow{4}{*}{ 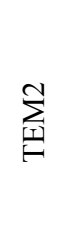 } & \multirow{4}{*}{ 等竞 } & \multirow{4}{*}{ 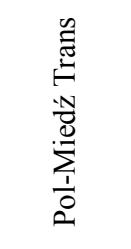 } & Tablica pneumatyczna lokomotywy & 45ZL 81-1 & \\
\hline & & & & Manipulator HZ-L & $1 \mathrm{ZH} 05-7$ & \\
\hline & & & & Manipulator HD & $1 \mathrm{ZH} 06-4$ & \\
\hline & & & & $\begin{array}{l}\text { Zawór hamulca bezpieczeństwa } \\
\text { DN25 }\end{array}$ & 7ZH 35-1 & \\
\hline & \multirow{4}{*}{ 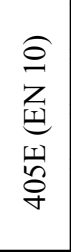 } & \multirow{4}{*}{ 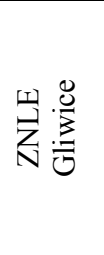 } & \multirow{4}{*}{ 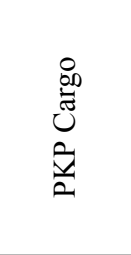 } & Tablica pneumatyczna lokomotywy & 45ZL 82-1 & \\
\hline & & & & Manipulator HZ-L & $1 \mathrm{ZH} 05-7$ & \\
\hline & & & & Manipulator HD & $1 \mathrm{ZH} 06-6$ & \\
\hline & & & & $\begin{array}{l}\text { Zawór hamulca bezpieczeństwa } \\
\text { DN25 }\end{array}$ & 7ZH 35-1 & \\
\hline \multirow{4}{*}{ ¿্ণ } & \multirow{8}{*}{$\stackrel{60}{6}$} & \multirow{8}{*}{$\begin{array}{c}\text { Newag } \\
\text { Nowy } \\
\text { Sącz }\end{array}$} & \multirow{8}{*}{$\begin{array}{c}\text { ISD Huta } \\
\text { Często- } \\
\text { chowa }\end{array}$} & Tablica pneumatyczna lokomotywy & 45ZL 83-1 & \\
\hline & & & & Manipulator HZ(8+P) & $1 \mathrm{ZH} 28-1$ & \\
\hline & & & & Manipulator HD & $1 \mathrm{ZH} 25-1$ & \\
\hline & & & & $\begin{array}{l}\text { Zawór hamulca bezpieczeństwa } \\
\text { DN25 }\end{array}$ & 7ZH 36-1 & \\
\hline \multirow{4}{*}{$\stackrel{\infty}{\stackrel{2}{\circ}}$} & & & & Tablica pneumatyczna lokomotywy & 45ZL 84-1 & \\
\hline & & & & Manipulator $\mathrm{HZ}(8+\mathrm{P})$ & 1ZH 28-1 & \\
\hline & & & & Manipulator HD & $1 \mathrm{ZH} 25-1$ & \\
\hline & & & & $\begin{array}{l}\text { Zawór hamulca bezpieczeństwa } \\
\text { DN25 }\end{array}$ & 7ZH 36-1 & \\
\hline
\end{tabular}

Manipulatory HZ-U i HD, wymienione w tabeli 1, zabudowano w lokomotywie w 2002 roku, podczas jej naprawy rewizyjnej (uwaga do tabeli 1). 
Tabela 2

Elementy produkcji IPS „TABOR”zastosowane w mikroprocesorowych ukladach sterowania hamulcami zmodernizowanych lokomotyw manewrowych

\begin{tabular}{|c|c|c|c|c|c|c|}
\hline \multirow[b]{2}{*}{$\frac{y}{0}$} & \multicolumn{3}{|c|}{ Dane lokomotywy } & \multirow{2}{*}{ Nazwa urządzenia } & \multirow{2}{*}{$\begin{array}{c}\text { Typ } \\
\text { urządzenia }\end{array}$} & \multirow{2}{*}{$\begin{array}{l}50 \\
5 \\
5 \\
3\end{array}$} \\
\hline & Tyр & $\begin{array}{l}\text { Moder- } \\
\text { nizator }\end{array}$ & $\begin{array}{c}\text { Użyt- } \\
\text { kownik }\end{array}$ & & & \\
\hline \multirow{3}{*}{ ㅎㅇㅇ } & \multirow{3}{*}{ 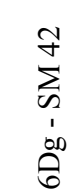 } & \multirow{11}{*}{ 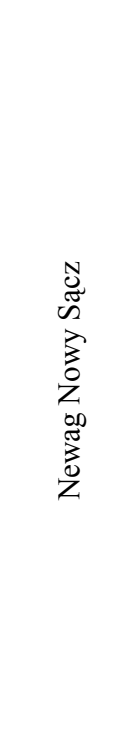 } & \multirow{3}{*}{ 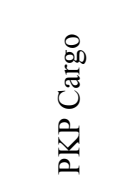 } & Tablica pneumatyczna lokomotywy & 45ZL 84-2 & \multirow{3}{*}{$* 1)$} \\
\hline & & & & Manipulator HZ(8+P) & $1 \mathrm{ZH} 28-1$ & \\
\hline & & & & Zawór hamulca bezpieczeństwa DN25 & 7ZH 36-1 & \\
\hline \multirow{4}{*}{$\overline{\vec{c}}$} & \multirow{4}{*}{$\theta^{\infty}$} & & \multirow{4}{*}{ 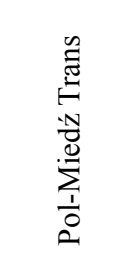 } & Tablica pneumatyczna lokomotywy & 45ZL 84-2 & \\
\hline & & & & Manipulator HZ(8+P) & 1ZH 28-1 & \\
\hline & & & & Manipulator HD & $1 \mathrm{ZH} 25-1$ & \\
\hline & & & & Zawór hamulca bezpieczeństwa DN25 & 7ZH 36-1 & \\
\hline \multirow{4}{*}{ 항 융 } & \multirow{4}{*}{$\underline{0}$} & & \multirow{4}{*}{ ב } & Tablica pneumatyczna lokomotywy & 45ZL 84-2 & \\
\hline & & & & Manipulator HZ(8+P) & $1 \mathrm{ZH} 28-1$ & \\
\hline & & & & Manipulator HD & $1 \mathrm{ZH} 25-1$ & \\
\hline & & & & Zawór hamulca bezpieczeństwa DN25 & 7ZH 36-1 & \\
\hline \multirow{4}{*}{ శ } & \multirow{4}{*}{ 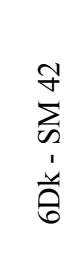 } & \multirow{4}{*}{ 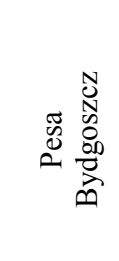 } & \multirow{4}{*}{ 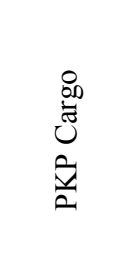 } & Tablica pneumatyczna lokomotywy & 60ZL 05-1 & \\
\hline & & & & Manipulator HZ(8+P) & $1 \mathrm{ZH} 28-1$ & \\
\hline & & & & Manipulator HD & $1 \mathrm{ZH} 25-1$ & \\
\hline & & & & Kabinowy zawór hamulca bezpieczeństwa & 7ZH 37-1 & \\
\hline \multirow{4}{*}{$\stackrel{m}{\stackrel{n}{2}}$} & \multirow{4}{*}{$\begin{array}{l}\stackrel{\infty}{+} \\
\sum_{\infty} \\
1 \\
\infty \\
n\end{array}$} & \multirow{4}{*}{ 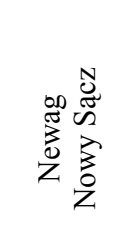 } & \multirow{4}{*}{ 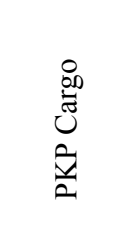 } & Tablica pneumatyczna lokomotywy & 45ZL 84-4 & \\
\hline & & & & Manipulator HZ-L & $1 \mathrm{ZH} 28-7$ & \\
\hline & & & & Manipulator HDi & $1 \mathrm{ZH} 20-2$ & \\
\hline & & & & Kabinowy zawór hamulca bezpieczeństwa & 7ZH 3901-1 & \\
\hline
\end{tabular}

IPS „TABOR” uczestniczył w kilku modernizacjach spalinowych lokomotyw manewrowych wyżej wymienionych typów oraz $\mathrm{w}$ modernizacji elektrycznej lokomotywy manewrowej typu 405E (seria PKP EM 10) opracowując dla nich układy sterowania hamulcami i rozrządem sprężonego powietrza oraz dostarczając najważniejsze zespoły tych układów, takie jak tablice pneumatyczne, elektryczne manipulatory hamulców i kabinowe zawory hamulca bezpieczeństwa (patrz tabele 1 i 2 ). W artykule tym przedstawiono rozwój tych układów od prostych układów elektropneumatycznych, w które wyposażono lokomotywy modernizowane na przełomie wieków, do zastosowanych ostatnio układów wykorzystujących sterowniki mikroprocesorowe i sieci informatyczne. Przedstawiono w nim również najnowsze rozwiązanie układu sterowania hamulcami i rozrządem sprężonego powietrza, który może znaleźć zastosowanie w modernizowanych lub nowych lokomotywach manewrowych; podstawowym zespołem tego układu jest uniwersalna tablica pneumatyczna o budowie modułowej (wersja z jednym zaworem rozrządczym).

\section{ZREALIZOWANE UKŁADY ELEKTROPNEU- MATYCZNE}

Pierwszy układ elektropneumatyczny lokomotywowej tablicy pneumatycznej (tablica typu 45ZL 10-1 zabudowana W lokomotywie serii SM 42 - 2000) wykonany w IPS „TABOR”przed dwudziestu laty dla lokomotywy zmodernizowanej przez ZNTK w Pile przedstawiono na (rys.1). 


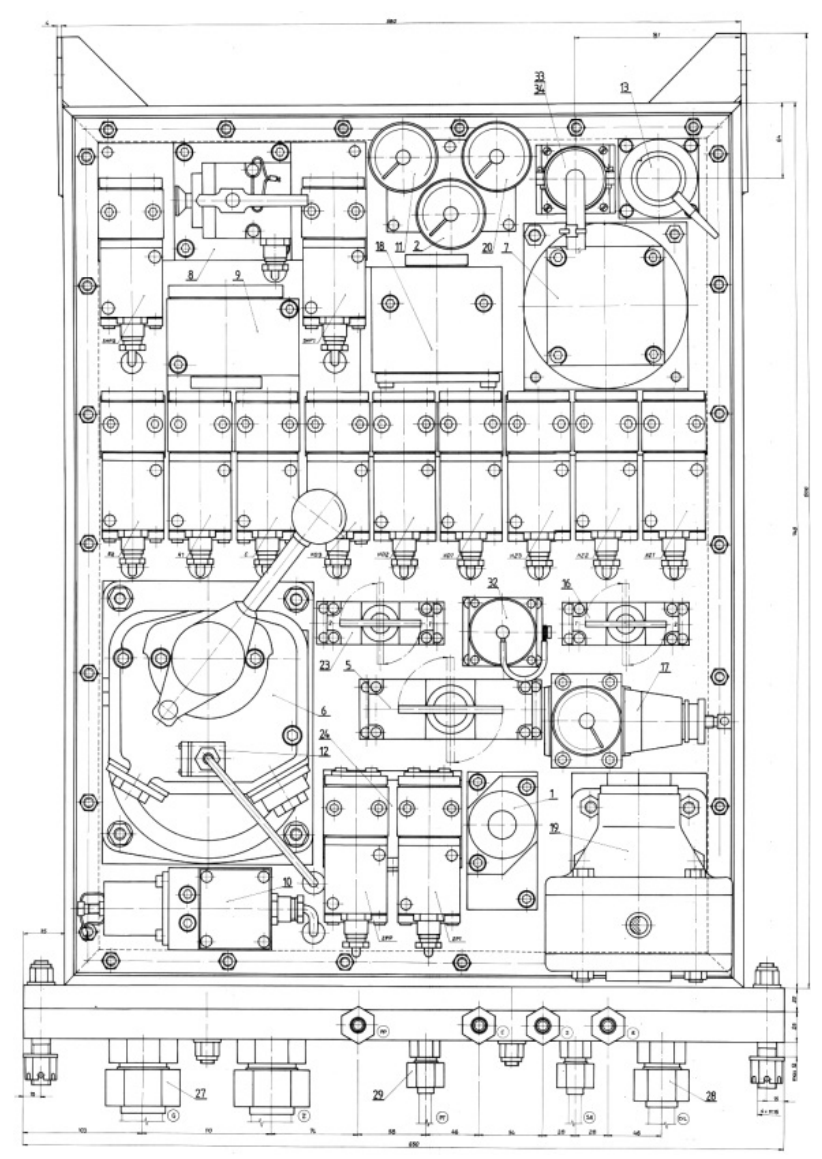

Rys. 1.Tablica pneumatyczna typu 45ZL 10-1

W układzie tym sterowanie hamulcami pneumatycznymi (zespolonym pociagu i dodatkowym lokomotywy) realizowanym $\mathrm{z}$ aktywnego stanowiska maszynisty, odbywało się za pośrednictwem tablicy pneumatycznej w sposób elektropneumatyczny. Sygnały binarne o napięciu baterii akumulatorów generowane przez manipulatory hamulców wzbudzały bezpośrednio duże, tablicowe zawory elektropneumatyczne (każdy o mocy 16W).

W sterowaniu hamulcem zespolonym pociagu pośredniczył główny zawór maszynisty typu H14E1 (Oerlikon Fv 4a) z unieruchomioną dźwignią sterującą zabudowany na tablicy, do której podłączono zbiornik trójkomorowy. Nominalne ciśnienie w przewodzie głównym wyznaczał regulator ciśnienia tego zaworu, przebiegi ciśnień niezbędne podczas luzowania hamulca wysokim ciśnieniem i wyrównania ciśnienia kształtowane były przez odpowiednie zespoły funkcjonalne tego zaworu uruchamiane tablicowymi zaworami elektropneumatycznymi. Natomiast wartość ciśnienia $\mathrm{w}$ przewodzie głównym wymaganą dla realizowanej funkcji hamulca utrzymywał przekładnik ciśnienia wchodzący w skład tego aparatu. Wartości ciśnienia $\mathrm{w}$ przewodzie głównym podczas hamowania służbowego kształtował układ złożony z regulatora ciśnienia wchodzącego w skład głównego zaworu maszynisty, modułu stopniującego HZ i trzech zaworów elektropneumatycznych współpracujących z tym modułem: (rys. 2).

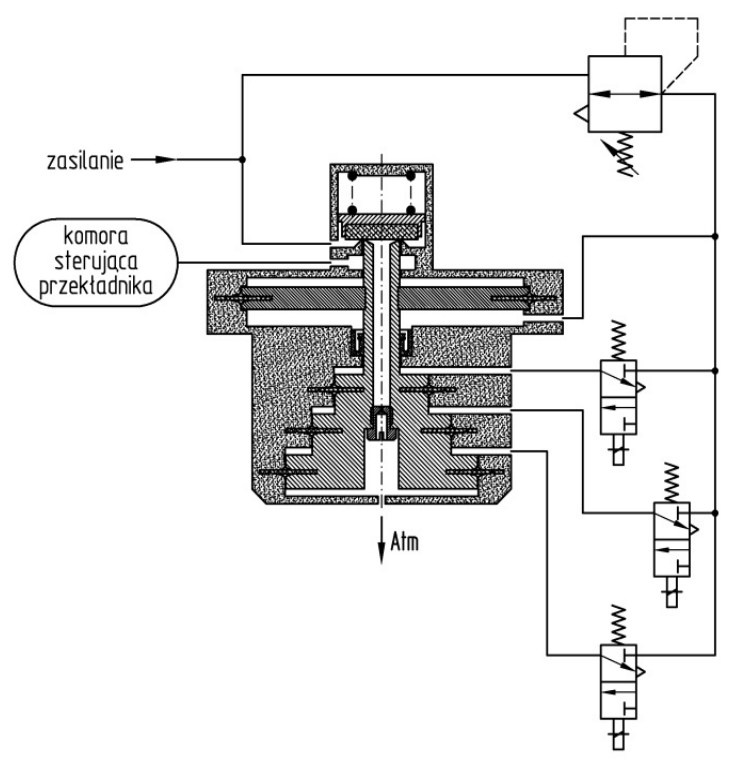

Rys. 2.Układ sterowania ciśnieniem przewodu głównego, zabudowany w tablicy typu 45ZL

Układ ten przekształcał kod złożony z trzech napięciowych sygnałów binarnych generowanych przez manipulator hamulca zespolonego w analogowy sygnał pneumatyczny (wartość ciśnienia odpowiadająca temu kodowi). W stanie gotowości hamulca, kiedy cewki zaworów elektropneumatycznych nie były pod napięciem, sprężone powietrze $\mathrm{z}$ regulatora naciskało tylko na dolną powierzchnię dużego tłoka modułu stopniującego. Ciśnienie na wyjściu tego aparatu było wtedy $\mathrm{w}$ przybliżeniu równe ciśnieniu $\mathrm{z}$ regulatora. $\mathrm{Na}$ każdym stopniu hamowania służbowego zawory elektropneumatyczne wzbudzane były w kombinacji właściwej dla tego stopnia. Sprężone powietrze $\mathrm{z}$ regulatora działa wtedy również na górne powierzchnie odpowiednich małych tłoków modułu stopniującego obniżając ciśnienie na jego wyjściu. Powierzchnie małych tłoków pozostają w proporcji jak $1: 2: 4$, co umożliwiało uzyskanie na wyjściu modułu stopniującego siedmiu różnych wartości ciśnienia niższych od ciśnienia z regulatora. Sumaryczna powierzchnia małych tłoków w tym aparacie jest taka, że po wzbudzeniu wszystkich zaworów elektropneumatycznych ciśnienie na wyjściu modułu stopniującego jest niższe od ciśnienia z regulatora o $160 \div 180 \mathrm{kPa}$. Taki spadek ciśnienia $\mathrm{w}$ przewodzie głównym względem wartości nominalnej wywołuje hamowanie pełne służbowe. Hamowanie nagłe inicjowane jest przerwaniem wzbudzenia dwóch tablicowych zaworów elektropneumatycznych. Za sprawa jednego z nich przekładnik ciśnienia głównego zaworu maszynisty odcina dopływ powietrza do przewodu głównego i łączy ten przewód $\mathrm{z}$ atmosferą poprzez wydrążenie $\mathrm{w}$ swoim trzonie. Za sprawą drugiego zaworu elektropneumatycznego otwiera się sterowany nim zawór hamowania nagłego DN25mm łącząc przewód główny $\mathrm{z}$ atmosferą przekrojem odpowiadającym jego średnicy 
nominalnej. Skutkiem współdziałania wyżej wymienionych aparatów tablicowych ciśnienie w przewodzie głównym szybko spada dążąc do wartości ciśnienia atmosferycznego. Te same zawory elektropneumatyczne pośredniczą też $\mathrm{w}$ wywołaniu hamowania nagłego przez lokomotywowe urządzenia nadzorujące ruch pociagu: tablicowy wyłącznik tych urządzeń umożliwia w razie ich awarii pneumatyczne i elektryczne odcięcie wyżej wymienionych zaworów. Wymaganie użytkownika dotyczące wyposażenia modernizowanej lokomotywy $\mathrm{w}$ drugi, działający niezależnie układ urządzeń umożliwiający wywołanie hamowania na polecenie radiostopu spełniono instalując obok tablicy pneumatycznej zespół hamowania nagłego sterowany elektrycznie (wymaganie to zostało wyrażone już po skonstruowaniu tablicy pneumatycznej). Jedynym stanem hamulca zespolonego niedostępnym $\mathrm{z}$ aktywnego stanowiska maszynisty jest stan odcięcia; wprowadzenie hamulca w ten stan wymagało przestawienia dźwigni sterującej zaworu maszynisty zabudowanego na tablicy. Również redundancyjne, pneumatyczne sterowanie hamulcem zespolonym, za pośrednictwem zabudowanego $\mathrm{w}$ kabinie maszynisty pneumatycznego rozdzielacza o działaniu impulsowym dostępne było po przestawieniu zaworu rozdzielającego zabudowanego na tablicy pneumatycznej.

Tablicowy układ pośredniczący w sterowaniu hamulcem dodatkowym lokomotywy tworzą zawór redukcyjny, moduł stopniujący HD i trzy zawory elektropneumatyczne współpracujące $\mathrm{z}$ tym modułem oraz jednostopniowy przekładnik ciśnienia typu H12E71 (Oerlikon D10). Układ ten działa na zasadzie wykorzystywanej od dawna do proporcjonalnego sterowania hamulcem elektropneumatycznym zespołów trakcyjnych. Jego zawory elektro-pneumatyczne wzbudzane są sygnałami z manipulatora hamulca dodatkowego w kombi-nacjach właściwych dla poszczególnych stopni hamowania tym hamulcem. Za ich pośrednictwem sprężone powietrze o największym ciśnieniu cylindrowym ustalonym za pomocą zaworu redukcyjnego dopływa do modułu stopniującego i naciska od dołu na odpowiednie powierzchnie potrójnego tłoka tego aparatu (patrz rys. 3 ).

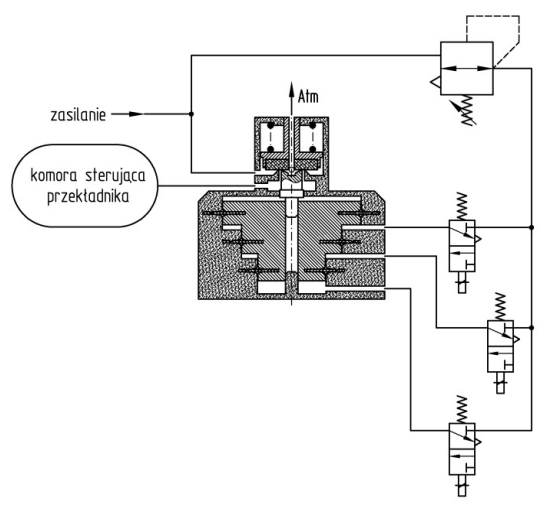

Rys3.Układ sterownia hamulcem dodatkowym, zabudowany w tablicy typu 45ZL 10-1
Siła ta równoważona jest ciśnieniem działającym na górną powierzchnię tłoka potrójnego, takie też ciśnienie występuje na wyjściu modułu stopniującego i jest utrzymywane w cylindrach hamulcowych przez sterowany nim przekładnik. Dolne powierzchnie tłoka potrójnego $\mathrm{w}$ module stopniującym HD również pozostają w proporcji jak 1 ? 2 ? 4, a ich powierzchnia sumaryczna jest równa $\mathrm{w}$ przybliżeniu powierzchni górnej tego tłoka. Umożliwia to uzyskanie na wyjściu modułu stopniującego siedmiu różnych wartości ciśnienia większych od ciśnienia atmosferycznego. Kiedy zawory elektropneumatyczne omawianego układu nie są wzbudzone, hamulec dodatkowy jest wyluzowany, po wzbudzeniu wszystkich zaworów ciśnienie na wyjściu modułu stopniującego jest $\mathrm{w}$ przybliżeniu równe nastawionemu zaworem redukcyjnym, co oznacza hamowanie pełne.

Korpus tablicy pneumatycznej pokazanej na rysunku 1 wykonany był w całości z elementów stalowych: jej płyta czołowa przytwierdzona była za pomocą śrub $z$ nakrętkami do ramy zespawanej z giętych ceowników. Każdy z aparatów tablicowych wyposażony był we własny wspornik wykonany ze stopu aluminium. Wsporniki te przytwierdzone były do płyty czołowej tablicy nitami zrywanymi, a osadzone we wspornikach gumowe pierścienie uszczelniające $\mathrm{i}$ mosiężne złączki z nakrętkami i pierścieniami zaciskowymi zapewniały szczelne połączenie aparatów tablicowych z elementami orurowania tablicy wykonanymi $\mathrm{z}$ rur i kształtek miedzianych lutowanych kapilarnie.

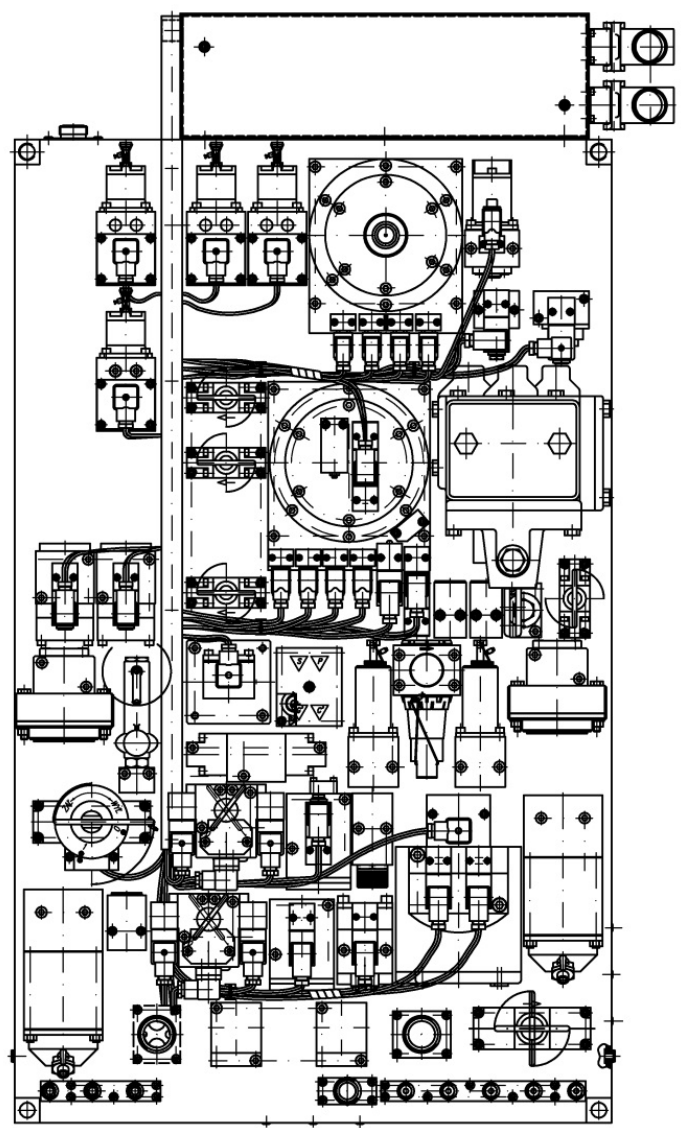

Rys.4.Tablica pneumatyczna typu 45ZL 81-1 
Rozwiązania zastosowane w tablicy pneumatycznej przedstawionej powyżej odpowiadają ówczesnym możliwościom produkcyjnym. IPS „TABOR” nie dysponował wtedy wystarczającym zestawem własnych aparatów do opracowania tablicy dorównującej tablicom oferowanym przez czołowych producentów. Jednakże doświadczenia zebrane podczas uruchomienia i eksploatacji lokomotywy z tą tablicą przyczyniły się do rozwoju układów sterowania hamulcami zastosowanych w kolejnych lokomotywach poddawanych modernizacji.

W tablicach kolejnych typów 45ZL 20-2, 45ZL 81-1 i 45ZL 82-1, które na przełomie wieków znalazły zastosowanie odpowiednio w lokomotywach zmodernizowanych przez PTKiGK w Rybniku (lokomotywy typu 6D), lokomotywach zmodernizowanych dla firmy Polmiedźtrans (lokomotywy typu TEM2) i w lokomotywach typu 405E zmodernizowanych przez ZNLE w Gliwicach pojawiają się już stosowane do dziś rozwiązania konstrukcyjne lepiej integrujące poszczególne aparaty i zespoły tablicy.

Na przykład korpus każdej z tych tablic (patrz rys. 4) wykonany był ze stopu aluminium, poprzez zespawanie $\mathrm{z}$ odpowiednio ugiętej, grubej płyty i prostopadłościennych elementów usztywniających umieszczonych w jego narożnikach (otwory w tych elementach służyły do zamocowania tablicy). Do tej pory stosowany jest też zastosowany w tych tablicach sposób wykonania instalacji pneumatycznej i mocowania aparatów tablicowych polegający na:

- zastosowaniu lutowanych kapilarnie miedzianych przewodów, których mosiężne głowice wyposażone w gumowe pierścienie uszczelniające osadzone są w otworach korpusu tablicy,

- osadzeniu w korpusie tablicy mosiężnych tulei gwintowanych do mocowania poszczególnych aparatów,

- zastosowaniu aparatów zasilanych płytowo, które mocowane śrubami do tych tulei przylegaja do głowic przewodów pneumatycznych, co zapewnia trwałe i szczelne połączenia pomiędzy elementami układu pneumatycznego tablicy.

W tablicach tej grupy w sterowaniu hamulcem zespolonym pociągu nadal pośredniczą zespoły funkcjonalne głównego zaworu maszynisty uruchamiane zaworami elektropneumatycznymi, jednak elementy tych zespołów zabudowane zostały w swoich korpusach tworząc oddzielne aparaty tablicowe (wyznacznik ciśnienia, zespół redukcyjny, zespół czasowy i przekładnik ciśnienia przewodu głównego). Do sterowania wykorzystano niewielkie zawory elektropneumatyczne o mocy $10 \mathrm{~W}$ albo $5 \mathrm{~W}$ zamocowane bezpośrednio do tych korpusów. Takie same zawory zabudowano też w zespole stopniującym HZ, który kształtuje wartości ciśnienia $\mathrm{W}$ przewodzie głównym podczas hamowania służbowego. Zespół ten funkcjonuje na takiej samej zasadzie jak moduł stopniujący HZ pokazany na (rys. 2), jednak dzięki zwiększeniu z trzech do czterech liczby małych tłoków aparat ten wraz $\mathrm{z}$ manipulatorem hamulca zespolonego zapewniają wymagane różne wartości ciśnienia $w$ przewodzie głównym na pierwszym stopniu hamowania (pozycja „1B” dźwigni manipulatora) i ostatnim stopniu luzowania (pozycja „1A” dźwigni manipulatora). Hamowanie nagłe realizowane jest w wyniku współdziałania przekładnika ciśnienia przewodu głównego i dwóch zespołów hamowania nagłego sterowanych elektrycznie. W skład takiego zespołu wchodzą zawór upustowy o średnicy nominalnej DN25mm i dwa zawory elektro- pneumatyczne sterujące tym zaworem. Jeden z zaworów sterujących, zasilany prądem za sprawą lokomotywowych urządzeń nadzorujących ruch pociągu, odcinany jest tablicowym wyłącznikiem tych urządzeń zabudowanym w wyżej wymienionym zespole.

Zgodnie z wymaganiami użytkowników modernizowanych lokomotyw jeden $\mathrm{z}$ zespołów hamowania nagłego sterowany jest sygnałem z układu samoczyn-

nego hamowania pociagu i czuwaka aktywnego, drugi sygnałem z układu radiostopu (dwa zespoły hamowania nagłego działające niezależnie). Zawory upustowe obu zespołów hamowania nagłego otwierają się natomiast jednocześnie $\mathrm{w}$ razie wywołania hamowania nagłego manipulatorem hamulca zespolonego, co wraz z odcięciem dopływu powietrza do przewodu głównego przez przekładnik ciśnienia zapewnia wymaganą redundancję tej funkcji i gwarantuje właściwy poziom bezpieczeństwa pojazdu. Bezpieczeństwo jazdy wymaga również, aby awaryjny zanik napięcia w obwodach sterowania hamulcem wywoływał hamowanie nagłe. Dlatego serwozawór ten jest serwozaworem normalnie otwartym, a odcięcie wyżej wymienionego układu od przewodu głównego w lokomotywie pozbawionej zasilania elektrycznego umożliwia tablicowy zawór odcinający sterowany ręcznie. Po jego zamknięciu lokomotywa w takim stanie może być holowana $\mathrm{z}$ działającym hamulcem zespolonym (sterowanym poprzez przewód główny z innego pojazdu trakcyjnego). Odcięcie tablicowego układu sterowania hamulcem zespolonym pociagu od przewodu głównego tego hamulca (niezbędne na przykład w lokomotywie sterowanej $\mathrm{w}$ trakcji wielokrotnej) zapewniał serwozawór elektropneumatyczny sterowany z aktywnego stanowiska maszynisty.

W sterowaniu hamulcem dodatkowym w każdej z tablic tej grupy pośredniczył ze-spół stopniujący HD, którego zasada działania nie różni się od zasady działania modułu pokazanego schematycznie na (rys. 3). W zespole tym zintegrowano cztery niewielkie zawory elektropneumatyczne, każdy o mocy $5 \mathrm{~W}$, a dolne powierzchnie jego poczwórnego tłoka pozostają w proporcji jak $1: 2: 4: 8$. W sterowaniu hamulcem dodatkowym wykorzystano tylko osiem poziomów ciśnienia $\mathrm{z}$ tego aparatu, jednak za sprawą odpowiedniego doboru ciśnienia na pierwszym stopniu hamowania przyrosty siły hamowania na stopniach kolejnych były w przybliżeniu jednakowe.

Tablice tej grupy realizowały hamowanie hamulcem zespolonym lokomotywy; służyły do tego standardowe zawory rozrządcze stosowane normalnie w wagonach. Typowym rozwiązaniem dla tablic tej grupy jest zawór typu SW4, charakteryzujący się dobrą odpornością na przeładowanie zbiornika sterującego i ogranicznikiem ciśnienia umożliwiającym współpracę zaworu ze zbiornikiem pomocniczym, w którym ciśnienie robocze sięga wartości $1000 \mathrm{kPa}$. Niektóre $\mathrm{z}$ tych tablic pośredniczą w sterowaniu sprężynowym hamulcem postojowym chroniąc przed sumowaniem się siły tego hamulca $\mathrm{z}$ siłą hamulca pneumatycznego (zespolonego lub dodatkowego) w przypadku jednoczesnego użycia tych hamulców. W tym celu sprężone powietrze napływające do cylindrów hamulcowych doprowadzane jest (poprzez podwójny zawór zwrotny zabudowany na tablicy) również do siłowników sprężynowych hamulca posto- 
jowego. Skutkiem tego jest zanik lub znaczne zmniejszenie siły hamowania hamulca postojowego. Tablice te $\mathrm{z}$ reguły realizują również rozrząd sprężonego powietrza dla pomocniczych układów pneumatycznych lokomotywy, takich jak piasecznice, zbiornik rozrządu i smarowanie obrzeży kół.

W układach sterowania hamulcem zespolonym pociagu wyżej opisanych tablic występują już elementy elektroniczne - przekaźniki czasowe umożliwiające wybór funkcji realizowanej przez przekaźnik i jej parametrów czasowych. Przekaźniki takie określają maksymalny czas trwania impulsu wysokiego ciśnienia podczas luzowania tego hamulca oraz czas otwarcia zaworu elektropneumatycznego niezbędny do wywołania pierwszego stopnia hamowania. Szersze zastosowanie techniki mikroprocesorowej następuje dopiero w tablicach typów 45ZL 83-1 i 45ZL 841wykonanych w latach 2007 i 2008 dla pierwszych lokomotyw typu 6Dg zmodernizowanych przez NEWAG dla huty w Częstochowie (patrz rys. 5).

W tablicach tych zastosowano mikroprocesorowe sterowniki produkcji IPS. Każdy z trzech jednakowych sterowników zastosowanych w pierwszej z tych tablic wyposażony jest $\mathrm{w}$ dziesięć wejść i trzynaście wyjść dla sygnałów binarnych i umożliwia zaprogramowanie funkcji logicznych i różnych zależności czasowych pomiędzy sygnałami wejściowymi a wyjściowymi. Sterowniki te działając indywidualnie przyjmują sygnały sterujące z lokomotywy i z aparatów tablicowych, a za pośrednictwem wyjść wzbudzane sa tablicowe zawory elektropneumatyczne realizujące wymagane funkcje oraz przekaźniki pośredniczące w wysyłaniu sygnałów diagnostycznych. Natomiast trzy różne sterowniki zabudowane $\mathrm{w}$ drugiej spośród wyżej wymienionych tablic, połączone zostały tablicową magistralą danych o formacie RS232 i tworzą rozproszony system sterowania automatycznego. Jeden $z$ tych sterowników przyjmuje sygnały binarne z lokomotywy, drugi - sygnały binarne i analogowe $\mathrm{z}$ aparatów tablicowych, natomiast trzeci steruje tablicowymi zaworami elektropneumatycznymi i przekaźnikami wysyłającymi sygnały diagnostyczne dla układu sterowania lokomotywą. Dzięki zastosowaniu w tej tablicy konwertera RS232/CAN systemy sterowania tablicy i lokomotywy komunikują się również z układem sterowania lokomotywą za pośrednictwem lokomotywowej magistrali danych o formacie CAN.

Sterowniki zabudowane w obu wyżej wymienionych tablicach wymagaja stabilnego napięcia zasilania. Źródłem takiego napięcia są tablicowe zasilacze 24V DC/24V DC, a napięciem tym zasilane są wszystkie aparaty tablicowe, $\mathrm{w}$ tym zawory elektropneumatyczne, co korzystnie wpływa na ich niezawodność. Zastosowanie w tych tablicach sterowników nie zmieniło zasadniczo sposobu sterowania hamulcami. Ciśnienie nominalne przewodu głównego i naj-

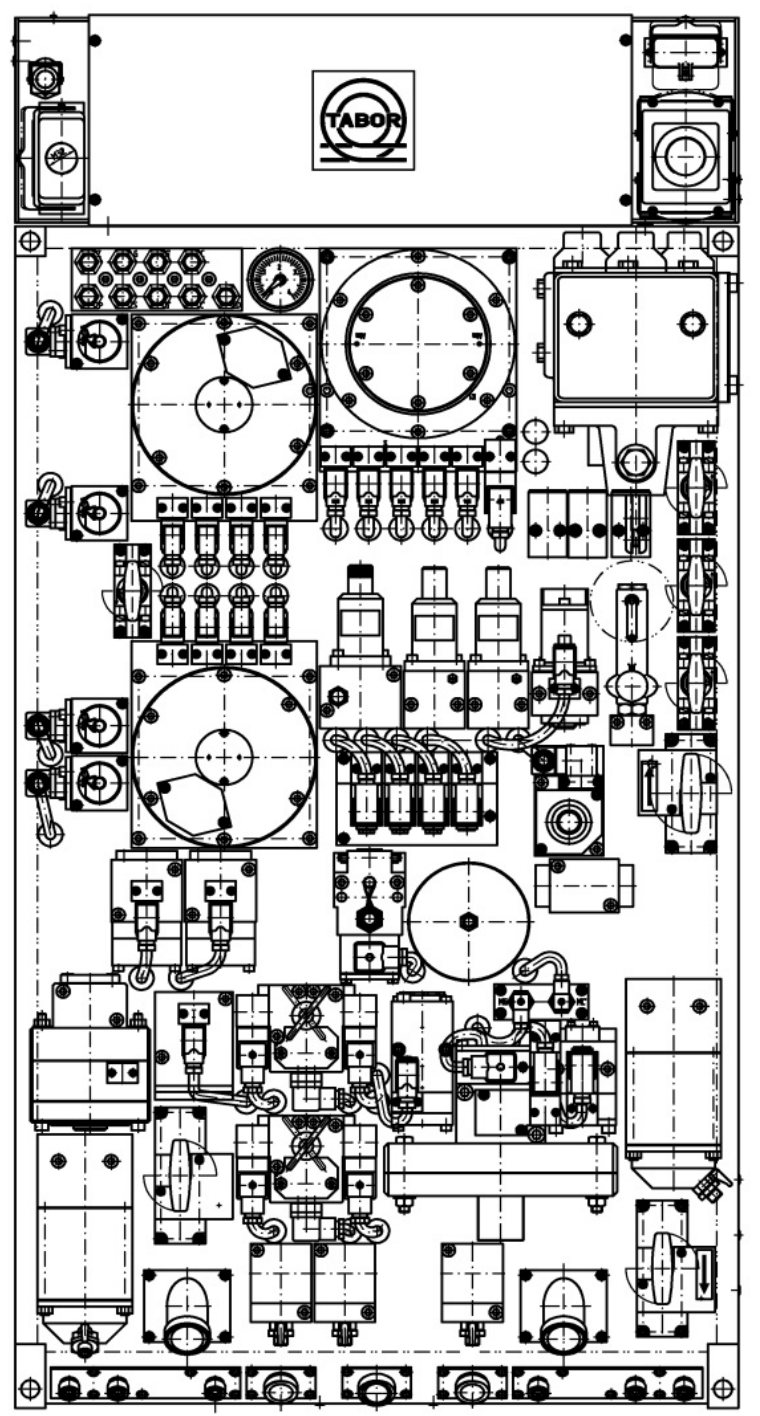

Rys 5. Tablica pneumatyczna typu 45ZL 84-1

większe ciśnienie cylindrowe hamulca dodatkowego nadal wyznaczane były za pomocą zaworów redukcyjnych, a wartości tych ciśnień podczas hamowań służbowych wyznaczały zespoły stopniujące. Dlatego układy sterowania hamulcami lokomotyw wyposażonych $\mathrm{w}$ te tablice zaliczono do elektropneumatycznych.

W układzie sterowania hamulcem zespolonym pociagu zabudowanym $\mathrm{w}$ tych tablicach nie występuja już elementy głównego zaworu maszynisty typu H14E1. Czas trwania impulsu rozpoczynającego luzowanie tego hamulca wysokim ciśnieniem określony jest $\mathrm{w}$ sposób programowy: zależy on od położenia dźwigni manipulatora $\mathrm{w}$ chwili naciśnięcia przez maszynistę na przycisk wywołujący takie luzowanie. Budowa i sposób działania aparatów tablicowych odpowiedzialnych za realizację tego impulsu w przewodzie głównym stosowane są do tej pory. W przekładniku ciśnienia przewodu głównego (rys. 6) kanał prowadzący do tego przewodu połączony jest z przestrzenią nad membraną przez normalnie otwarty zawór elektropneumatyczny $3 / 2$. W celu wywołania 
impulsu wysokiego ciśnienia połączenie to jest przerywane na skutek czego przekładnik działa wówczas jak serwozawór. Pełnym przekrojem przekładnika napływa wtedy sprężone powietrze do przewodu głównego o ciśnieniu panującym w zbiorniku głównym lokomotywy. Po przerwaniu wzbudzenia zaworu elektropneumatycznego przekładnik powraca do normalnej funkcji przekładnika; ciśnienie w przewodzie głównym spada do poziomu około $540 \mathrm{kPa}$, po czym powoli obniża się wraz z ciśnieniem sterującym (wyrównanie ciśnienia stanowiące drugą fazę luzowania hamulca wysokim ciśnieniem).

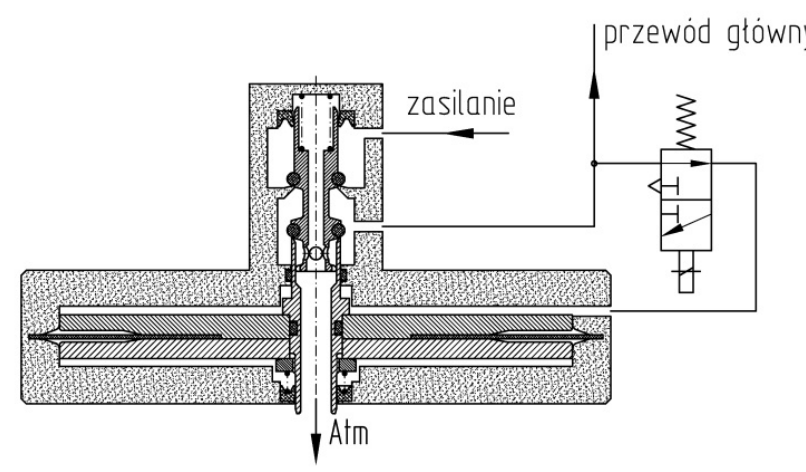

Rys. 6. Przekładnik ciśnienia przewodu głównego

W tablicy typu 45ZL 84-1 zabudowano układ umożliwiający współpracę hamulców pneumatycznych lokomotywy z jej hamulcem elektrodynamicznym. Funkcję tę realizuje przekładnik ciśnienia cylindrów hamulcowych pokazany schematycznie na (rys. 7). Kiedy hamulec elektrodynamiczny (hamulec ED) nie działa, wtedy działanie ciśnienia sterującego przekładnikiem na jego dolną membranę równoważy ciśnienie cylindrowe działające na membranę górną. Żądana siła hamowania, określona ciśnieniem sterującym realizowana jest tylko hamulcem pneumatycznym. Ciśnienie sterujące mierzone jest przetwornikiem „MC”, a sygnał o jego wartości przesyłany jest po magistrali danych CAN do sterownika hamulca ED, jako żądana (zadana) siła hamowania tym hamulcem. Po rozwinięciu przez hamulec ED siły hamowania informacja o jej wartości przesyłana jest do tablicy $\mathrm{w}$ ten sam sposób $\mathrm{w}$ formie kodu binarnego złożonego z czterech sygnałów. Kod ten przekształcany jest przez zespół stopniujący hamulca ED (taki sam jak zespół stopniujący hamulca dodatkowego) w analogowy sygnał ciśnieniowy. Pełne wykorzystanie możliwości zespołu stopniującego umożliwia uzyskanie piętnastu poziomów ciśnienia tego sygnału: ciśnienie z zespołu stopniującego wystarczająco dokładnie odpowiada wartości siły hamowania hamulcem ED.

Po rozwinięciu przez hamulec ED siły hamowania działanie ciśnienia sterującego na odpowiednią membranę przekładnika pokazanego na (rys. 7) równoważone jest sumarycznym działaniem ciśnienia cylindrowego i ciśnienia z zespołu stopniującego hamulca

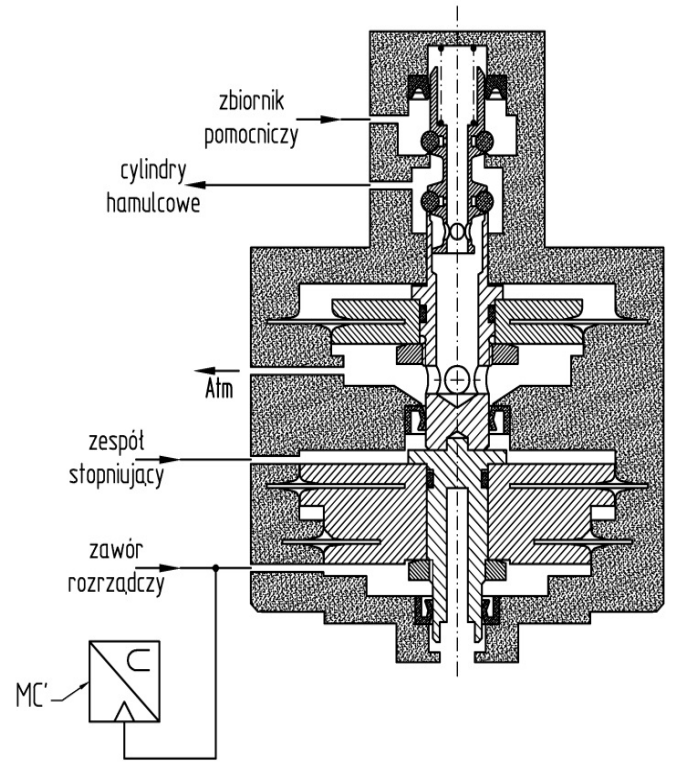

Rys.7. Przekładnik ciśnienia, sterujący współpracą hamulców pneumatycznych

ED. Dzięki temu hamowanie hamulcem ED jest w razie potrzeby $\mathrm{w}$ sposób samoczynny i płynny uzupełniane albo zastępowane hamowaniem pneumatycznym. Natomiast kiedy realizowana siła hamowania hamulcem ED jest równa sile żądanej, to działania ciśnienia sterującego i ciśnienia z zespołu stopniującego hamulca ED równoważą się. Ciśnienie w cylindrach hamulcowych jest wtedy równe atmosferycznemu, a lokomotywa hamowana jest tylko hamulcem ED.

Elektropneumatyczne układy sterowania hamulcami opisane powyżej nadal są użytkowane i działają z dokładnością wystarczającą dla bezpiecznego użytkowania lokomotyw. Zawory redukcyjne i zespoły stopniujące zastosowane $w$ tych układach są jednak obarczone histerezą i dlatego trudno za ich pomoca spełnić niektóre wymagania (na przykład utrzymanie $\mathrm{z}$ dokładnością do $\pm 5 \mathrm{kPa}$ nominalnej wartości ciśnienia $\mathrm{w}$ przewodzie głównym zespolonego hamulca pneumatycznego). Wadą tych układów są też znaczne wymiary zespołów stopniujących i nierównomierne stopniowanie ciśnienia. Wady te i dostępność sterowników mikroprocesorowych i przetworników do pomiaru ciśnien sprawiły, ze w tablicach pneumatycznych kolejnych typów zastosowano mikroprocesorowe, automatyczne układy regulacji ciśnienia ze sprężeniem zwrotnym opisane w kolejnych rozdziałach.

\section{ZREALIZOWANE UKŁADY MIKROPROCE- SOROWE}

Układy sterowania, w których przebiegi ciśnienia w przewodzie głównym hamulca zespolonego i w cylindrach hamulcowych podczas hamowania hamulcem dodatkowym kształtowane są za pomocą mikroprocesorowych układów automatycznej regulacji ze sprzężeniem zwrotnym wymieniono w tabeli 2. 
W układach tych występuja dwie grupy tablic pneumatycznych. Jedną grupę tworzą tablice typów 45ZL 84-2 i 45ZL 84-4 (rys. 8) stosowane w różnych wersjach w lokomotywach modernizowanych przez Newag.

Wersje te różnią się największą wartością ciśnienia cylindrowego (zależy to od typu lokomotywy poddawanej modernizacji) oraz sposobem sterowania hamulcem dodatkowym $\mathrm{z}$ aktywnego stanowiska maszynisty (zgodnie z życzeniem zamawiającego może to być sterowanie proporcjonalne albo impulsowe). Tablice tej grupy zaprojektowano w taki sposób, aby realizowały sterowanie współpracą hamulców pneumatycznych lokomotywy z jej hamulcem elektrodynamicznym (hamulcem ED). W tym celu w każdej $z$ tych tablic zabudowany jest przekładnik ciśnienia cylindrowego przystosowany do tej funkcji (patrz rys. 7) i trzeci układ automatycznej regulacji ciśnienia, którego zadanie polega na przekształcaniu przesyłanego po magistrali danych CAN sygnału o sile hamowania hamulca ED w analogowy sygnał pneumatyczny o ciśnieniu proporcjonalnym do tej siły (sygnał ten przeznaczony jest dla wyżej wspomnianego przekładnika). Elementy tego układu nie sa jednak instalowane, gdyż dotychczasowe modernizacje lokomotyw nie obejmowały wyposażenia ich w hamulec ED.

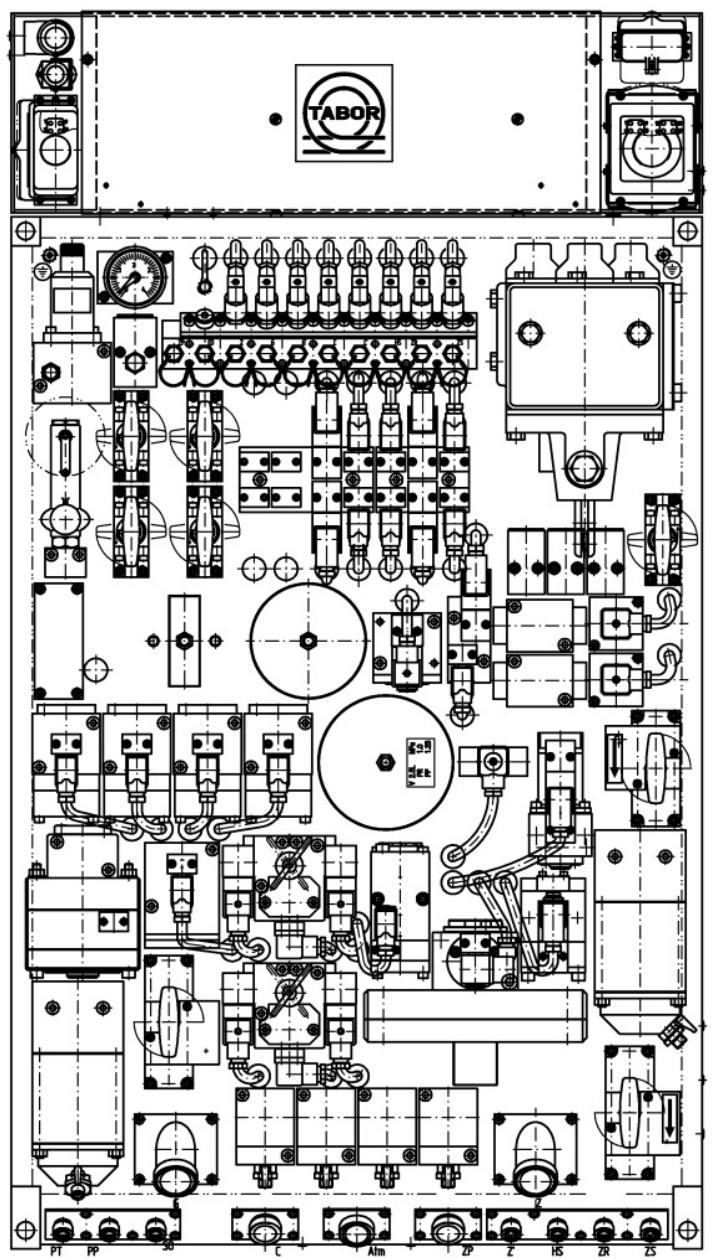

Rys.8. Tablica pneumatyczna typu 45ZL 84-4
Druga grupa to trzy wersje tablicy typu 60ZL 05-1 (rys. 9) przeznaczone dla modernizowanych przez Pesę lokomotyw typu 6D wyposażonych w wózki różnych typów. Tablice te nie realizują funkcji związanej $\mathrm{z}$ hamulcem ED, a zastosowany $\mathrm{w}$ nich przekładnik ciśnienia cylindrowego z przełożeniem regulowanym mechanicznie umożliwia płynne ustawienie wymaganej wartości największego ciśnienia cylindrowego. W lokomotywie z tablicą tej grupy funkcjonują dwa tryby sterowania jazdą i hamowaniem. W trybie liniowym sterowanie to jest możliwe tylko $\mathrm{z}$ jednego stanowiska maszynisty, $w$ trybie manewrowym sterowanie może się odbywać jednocześnie z obu stanowisk. Układy pomocnicze zasilane za pośrednictwem tablic tej grupy to - oprócz piasecznic, zbiornika rozrządu i smarowania obrzeży kół podłączonych również do tablic typów 45ZL 84-2 i 45ZL 84-4 - syreny wysokotonowa i niskotonowa.

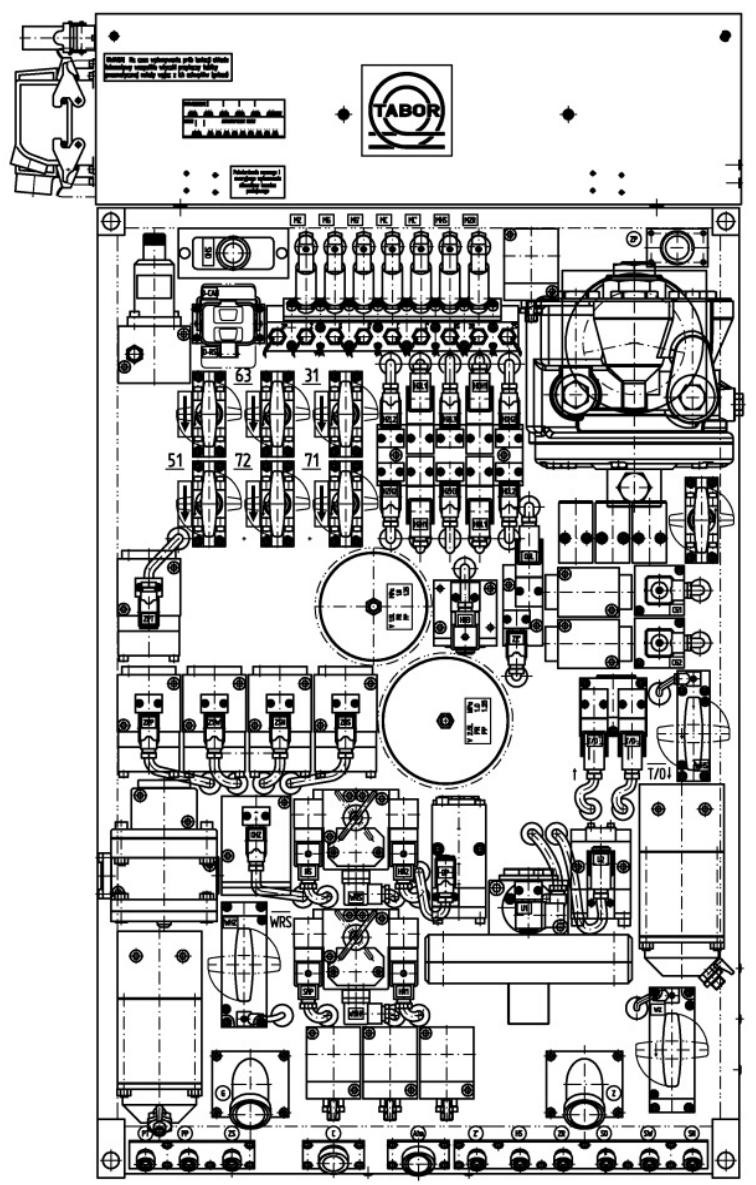

Rys.9. Tablica pneumatyczna typu 60ZL 05-1

Mikroprocesorowy układ regulacji ciśnienia w przewodzie głównym (rys. 10) tworzą następujące aparaty:

- trzy zawory elektropneumatyczne wyposażone w dysze o różnych zdolnościach przepustowych napełniające komorę sterującą przekładnika ciśnienia przewodu głównego,

- trzy zawory elektropneumatyczne z dyszami regulacyjnymi opróżniające tę komorę, 
- $\quad$ przetwornik do pomiaru ciśnienia w wyżej wspomnianej komorze

podłączone do jednego ze sterowników rozproszonego systemu sterowania automatycznego, który działa w tablicy. Drugi przetwornik podłączony do tego sterownika mierzy ciśnienie w przewodzie głównym. Wymagane wartości ciśnienia w komorze sterującej wynikają $\mathrm{z}$ sygnałów docierających $\mathrm{z}$ aktywnego stanowiska maszynisty. Dla ich uzyskania we właściwym tempie sterownik otwiera zawór lub kombinację zaworów o odpowiedniej zdolności przelotowej. W ten sposób uzyskuje się zarówno szybki spadek ciśnienia wymagany dla hamowania nagłego, jak i spadek w tempie określonym w karcie UIC 541-03 [1] dla hamowania służbowego (o $150 \mathrm{kPa} /(6 \div 10 \mathrm{~s})$ bądź w tempie wymaganym w tej samej karcie podczas wyrównania ciśnienia $(0,25 \div$ $0,2 \mathrm{kPa} / \mathrm{s})$.

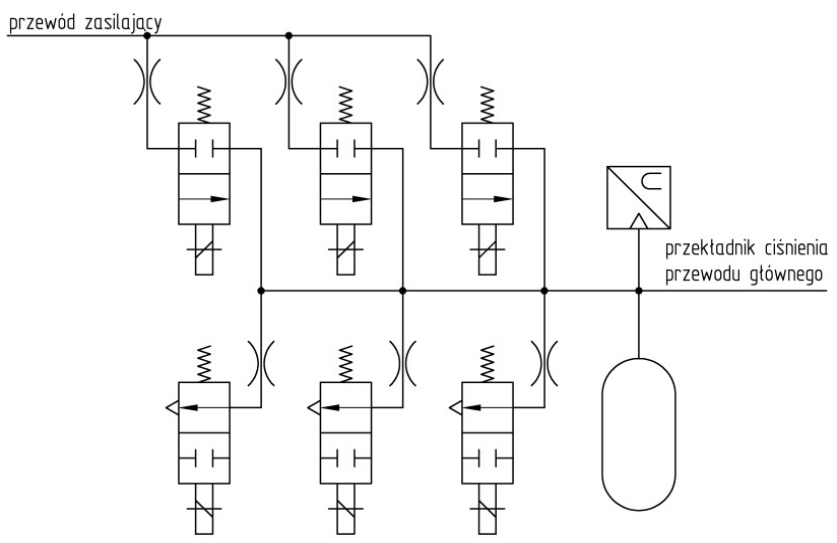

Rys.10. Mikroprocesorowy układ regulacji ciśnienia w przewodzie głównym

Podobnie przedstawia się układ sterowania ciśnieniem w komorze sterującej przekładnika cylindrów hamulcowych. Ze względu na mniejsze zróżnicowanie wymaganych gradientów wzrostu i spadku ciśnienia w tej komorze występują w nim tylko dwa zawory napełniające i dwa zawory opróżniające podłączone do innego ze sterowników wraz z przetwornikami do pomiaru ciśnień.

Takie układy do regulacji ciśnień, prostsze od elektropneumatycznych zapewniają dokładniejsze kształtowanie ich przebiegów i większe możliwości diagnostyczne. Dalszy rozwój tych układów polega na zastosowaniu szybszych sterowników i przetworników sygnałów elektrycznych na wartość ciśnienia, umożliwiających uzyskanie przebiegów opisanych funkcjami matematycznymi. Propozycję układu sterowania opartego na takim działaniu opracowanego $\mathrm{w}$ IPS „TABOR”dla lokomotyw manewrowych przedstawiono w kolejnym rozdziale.

\section{UKŁAD Z UNIWERSALNĄ TABLICĄ MODU- ŁOWA}

Modułową, uniwersalną tablicę pneumatyczną dla lokomotyw, opisaną w opracowaniu [2] skonstruowano w IPS „TABOR” $z$ uwzględnieniem aktualnych wymagań zawartych $\mathrm{w}$ technicznych specyfikacjach interoperacyjności (TSI), normach europejskich (EN) i aktualnych kartach UIC. Rozwiązanie to, jest platformą konstrukcyjno-technologiczną, umożliwiająca bardzo szybkie przygotowanie i wdrożenie do produkcji tablicy pneumatycznej właściwej dla danego pojazdu. Tablica taka składa się z następujących segmentów:

- głównego segmentu hamulcowego mieszczącego urządzenia do sterowania hamulcem zespolonym pociagu oraz hamulcami zespolonym, dodatkowym i spręży-nowym postojowym lokomotywy, oraz sterownik nadzorujący pracę tych urządzeń,

- segmentu układów pomocniczych mieszczącego urządzenia odpowiedzialne za rozrząd sprężonego powietrza dla tych układów,

- segmentu sterowniczego mieszczącego urządzenia, które przyjmują sygnały sterujące $\mathrm{z}$ lokomotywy oraz przyłącza niezbędne do zasilania tablicy i jej komunikacji z lokomotywowym układem sterowania.

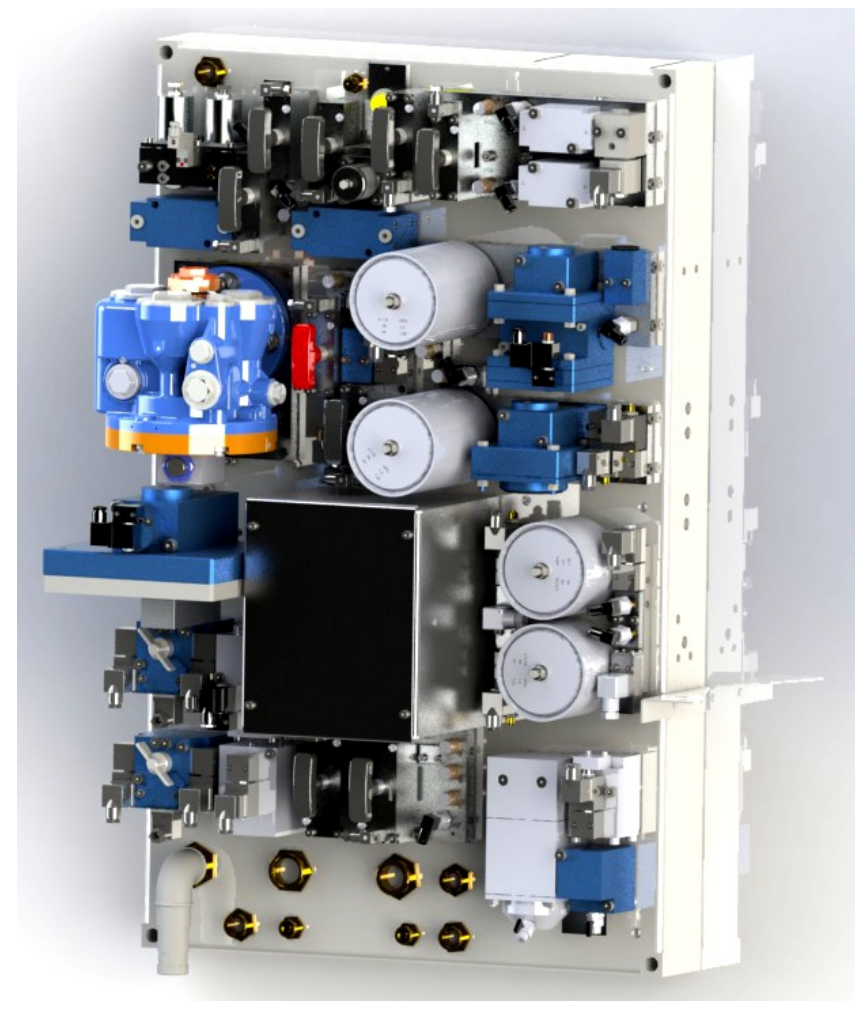

Rys.11. Główny segment hamulcowy uniwersalnej tablicy pneumatycznej 
Korpus głównego segmentu hamulcowego jest zarazem korpusem tablicy. Do niego w formie nadstawki przytwierdzony jest korpus segmentu układów pomocniczych. Segment sterowniczy może być przymocowany do segmentu hamulcowego albo zabudowany w innym, dogodnym miejscu i połączony z nim wiązką przewodów elektrycznych. Cechą charakterystyczną prezentowanego tu rozwiązania jest stosowanie $\mathrm{w}$ różnych tablicach takich samych modułów funkcjonalnych. Propozycję głównego segmentu hamulcowego uniwersalnej tablicy pneumatycznej znajdującej zastosowanie dla dowolnej lokomotywy manewrowej pokazano na (rys. 11). Jest to segment $z$ jednym zaworem rozrządczym, Większość aparatów i modułów zabudowanych $\mathrm{w}$ tym segmencie stosowanych jest również $\mathrm{w}$ segmencie $\mathrm{z}$ dwoma zaworami rozrządczymi, właściwym dla lokomotyw liniowych. Nowe rozwiązania tego segmentu to zastosowanie sterownika trzydziestodwu bitowego, który składa się $\mathrm{z}$ procesora centralnego oraz modułów wejściowych i wyjściowych, a także wykorzystanie do kształtowania przebiegów ciśnień zaworów proporcjonalnych. Prace tych zaworów nadzoruje wyżej wspomniany sterownik zapewniając im zasilanie za pośrednictwem przetwornic impulsowych. Układ ten umożliwia realizację przebiegów ciśnień opisanych matematycznymi funkcjami liniowymi lub nieliniowymi.
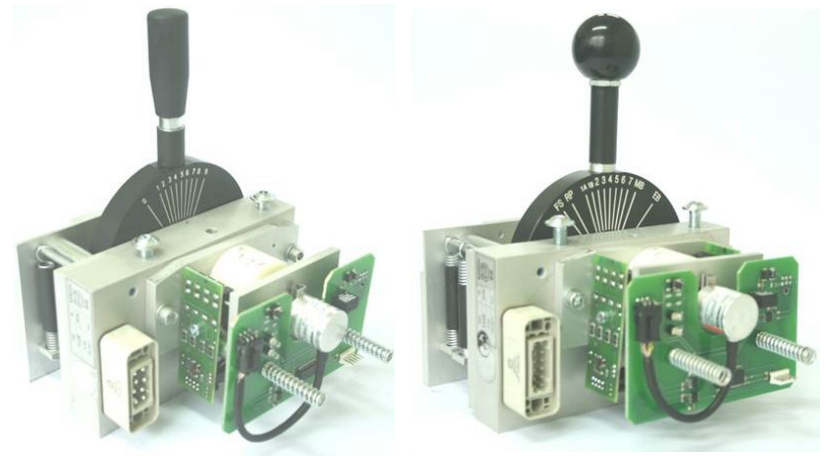

Rys. 12. Manipulatory hamulców zespolonego i dodatkowego, produkowane przez IPS TABOR

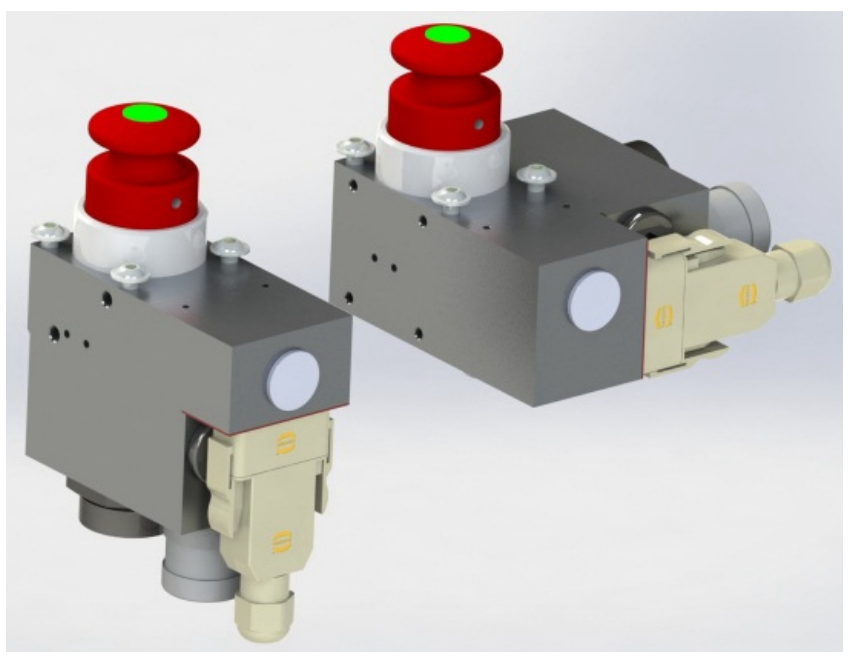

Rys 13. Kabinowy zawór hamulca bezpieczeństwa, produkowany przez IPS TABOR

Istotnymi elementami proponowanego układu sterowania są opracowane i wdrożone do produkcji przez IPS „TABOR”manipulatory hamulca i kabinowe zawory hamulca bezpieczeństwa. Urządzenia te spełniają aktualnie obowiązujące wymagania przepisów europejskich. Urządzenia te pokazano na (rys. 12 i 13).

\section{LITERATURA}

1. Karta UIC 541-03 „Hamulec Wymagania dla różnych części hamulca. Układ zaworu hamulcowego maszynisty" - wydanie 1 1984-01-01;

2. Kaluba M, Goliwas D. - "Modutowa uniwersalna tablica pneumatyczna dla lokomotyw spalinowych i elektrycznych" - Pojazdy Szynowe 03/2014. 